\title{
EFFECT OF LAKE WORTH AND SOUTH LAKE WORTH \\ INLETS ON THE MOVEMENT OF LIT'TORAL MATERIAL
}

\author{
Edwin W. Eden, Jr. \\ Chief, Planning and Reports Branch, Engineering Division \\ U. S. Army Engineer District, Jacksonville \\ Corps of Engineers, Jacksonville, Florida
}

\section{INTRODUCTION}

\section{DESCRIPTION}

Lake Worth and South Lake Worth Inlets are artificial inlets connecting Lake Worth with the Atlantic Ocean. They are located on the east coast of Florida about 70 miles north of Miami and 300 miles south of Jacksonville. Lake Worth is a salt-water sound extending in a north-south direction, generally parallel to the ocean shore, as shown on figure 1 . It is separated from the ocean by a barrier beach, 250 feet to about 3,600 feet wide and up to about 25 feet in elevation. The barrier beach is composed principally of sand, a portion of which is artificial fill over former low-lying marshy areas. There are occasional outcroppings of coquina rock on the barrier beach and in the offshore area. In this locality the offshore bottom is rather steep; the 100-fathom depth, lying closer to the shore than along other parts of the Atlantic coast, is about $5-1 / 2$ miles offshore at Lake Worth Inlet.

Lake Worth Inlet was dredged through the barrier beach by local interests between 1918 and 1925 to develop the Port of Palm Beach. It replaced the relatively unstable natural inlet through the barrier beach several miles to the north. Two protective jetties were constructed, parallel and 800 feet apart. At the time of construction, they extended out to approximately 20-foot depth in the ocean. The north and south jettles are about 2,000 and 1,900 feet long, respectively, both measured from the 1920 shoreline. A channel 20 feet deep, 300 feet wide through the inlet and thence 200 feet wide across Lake Worth, was provided to serve the terminals of the Port of Palm Beach, located on the west shore of Lake Worth. A Federal project for maintenance of the harbor and jetties was adopted by the River and Harbor Act of August 30, 1935. In order to meet the needs of shipping in the area, the River and Harbor Act of March 2, 1945, authorized deepening of the channel and turning basin to 25 feet below mean low water. That work was completed in 1949. The location and alinement of the existing project are shown on figure 2. Palm Beach County, in cooperation with local municipalities, is constructing a sand-transfer plant on the north side of the inlet which will maintain the predominantly southerly flow of littoral drift.

South Lake Worth Inlet connects Lake Worth with the ocean near the southerly end of the lake. The inlet was dredged through the barrier beach by local interests in 1927 to provide better tidal circulation in the lake for relief of unsanitary conditions. That work provided an 8by 125-foot channel which is used by small commercial and recreational craft. The inlet is protected by two parallel jetties about 300 feet long 
COASTAL ENGINEERING

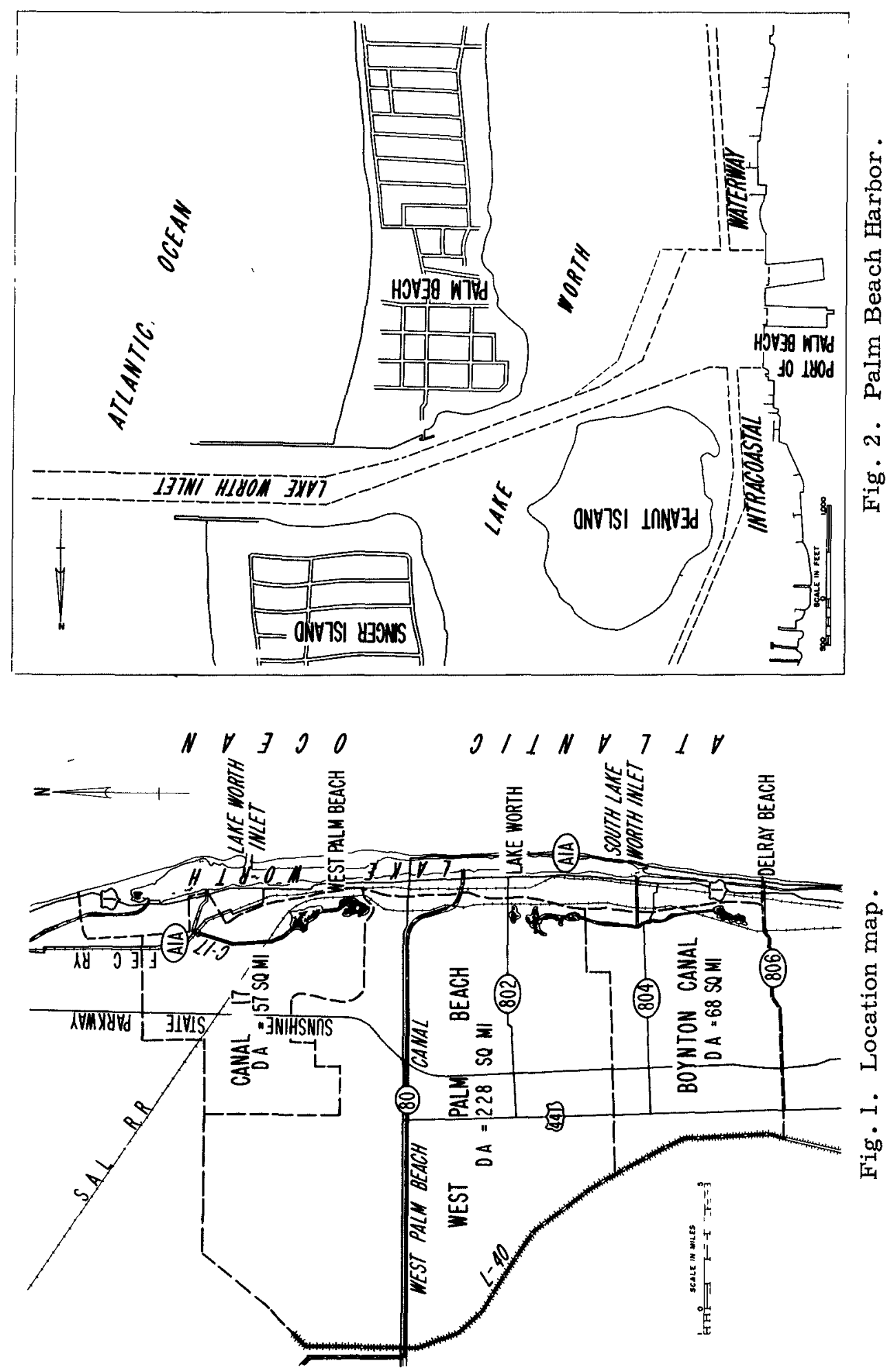




\section{EFFECT OF LAKE WORTH AND SOUTH LAKE WORTH \\ INLETS ON THE MOVEMENT OF LITTORAL MATERIAL}

which were initially constructed to the 6-foot depth contour. The jetties were initialiy built to a top elevation of 5 feet above mean low water. The north jetty was raised to a height of 12 feet above mean low water in 1936 when its capacity for impounding beach material was exhausted. At that time private interests installed a sand pump near the end of the north jetty to permit transfer of impounded littoral material to the beach south of the inlet, for the primary purpose of reducing erosion of shorefront property. In restoring the natural flow of littoral material, that installation has also materially reduced erosion in the reach south of the inlet.

Lake Worth ranges from $1 / 4$ to $1-1 / 2$ miles in width and is about 20.6 miles long. It has a surface area of about 13 square miles. Natural depths are generally less than 8 feet. West Palm Beach Canal, Boynton Canal, and Earman River are the major tributaries. Under present conditions, they serve 228,68 , and 57 square miles respectively. Within the last 10 years, major drainage improvements by local interests and by the Federal and State governments under the Central and Southern Florida Flood Control Project have increased the rate of discharge into the lake. Additional improvements are authorized. The total drainage area of Lake Worth, including the surface of the lake and the area which drains directly into the lake, is about 400 square miles. Estimated peak discharge to the lake is given in the following tabulation.

TABLE 1

Estimated peak inflow into Lake Worth (c.f.s.)

\begin{tabular}{ccccc}
\hline Storm & $\begin{array}{c}\text { West Palm } \\
\text { Beach } \\
\text { Canal }\end{array}$ & $\begin{array}{c}\text { Boynton Earman River } \\
\text { Canal }\end{array}$ & $\begin{array}{c}\text { Lake } \\
\text { surface } \\
\text { and local } \\
\text { area }\end{array}$ & $\begin{array}{c}\text { Maximum } \\
\text { rate of } \\
\text { inflow }\end{array}$ \\
\hline
\end{tabular}

\section{AS RECORDED}

$1947-19,290$

1953

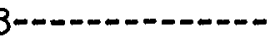

2,500
1,500
700

500
5,000

2,500
13,000

8,000

\section{UNDER PRESENT CONDITIONS}

$\begin{array}{lrrrrr}\text { Maximum annual-.-- } & 3,300 & 900 & 750 & - & - \\ 10 \text {-year storm-.-- } & 4,700 & 1,850 & 1,800 & 3,400 & 9,700 \\ 100 \text {-year storm-.-- } & 6,400 & 2,700 & 2,100 & 8,700 & 19,300\end{array}$

$I_{\text {Considering time of concentration. }}$

Depending on rainfall, the volume of inflow during any day will vary from practically zero to the maximum indicated in table 1 . For periods of several months or more during a normal dry season, November through May, the volume of inflow will be practically zero. 


\section{COASTAL ENGINEERING}

Lake Worth, for its entire length, forms a link in the Intracoasta: Waterway from Jacksonville to Miami. The existing channel, 8 feet deep and 100 feet wide, was authorized by the River and Harbor Acts of Januas 21; 1927, and July 3, 1930, and completed in 1935. Enlargement of the existing project to provide a channel 12 feet deep and 125 feet wide wa: authorized by the River and Harbor Act of March 2, 1945.

\section{LITTORAL FORCES}

GENERAL

The predominant flow of littoral material is from north to south, although during the summer months a reverse flow from south to north pre vails. That movement is due to the exposure of the area to winds and waves, swells, and tidal currents, including the Gulf Stream which flows northerly several miles offshore.

\section{WINDS}

The yearly average offshore winds in the Atlantic Ocean at Palm Bet summarized in table 2 are from the United States Hydrographic Office rec ords of winds reported by ships at sea during the period 1879 to 1933.

\section{TABLE 2}

\section{Yearly average offshore winds}

\begin{tabular}{|c|c|c|c|}
\hline & $\begin{array}{c}\text { Percentage } \\
\text { of time }\end{array}$ & $D$ & $\begin{array}{c}\text { Percentage } \\
\text { of time }\end{array}$ \\
\hline
\end{tabular}

\begin{tabular}{llll} 
North & 10 & Southwest & 6 \\
Northeast & 16 & West & 5 \\
East & 22 & Northwest & 8 \\
Southeast & 20 & Calm & 3 \\
South & 10 & & \\
\hline
\end{tabular}

The records indicate that winds from the south and southeast are experienced for longer periods than from any other sector--excluding those frc the east which have insignificant effect on littoral movement; however, predominant offshore winds in the area are from the north and east, with the strongest winds from the northern sector.

The direction, duration, and velocity of the wind were observed eve 6 hours by the United States Weather Bureau at West Palm Beach during th period July 1, 1938, to JuIy 31, 1946. The results of those observatior are summaxized in table 3 and on figure 3. 


\section{EFFECT OF LAKE WORTH AND SOUTH LAKE WORTH INLETS ON THE MOVEMENT OF LITTORAL MATERIAL TABLE 3}

Wind duration and direction--West Palm Beach

\begin{tabular}{lrlr}
\hline Direction & $\begin{array}{c}\text { Percentage } \\
\text { of time }\end{array}$ & Direction & $\begin{array}{c}\text { Percentage } \\
\text { of time }\end{array}$ \\
\hline North---.-- & 5 & South & 6 \\
Northeast-- & 15 & Southwest & 12 \\
Fast---.-- & 9 & West & 4 \\
Southeast-- & 32 & Northwest & 17 \\
\hline
\end{tabular}

The records indicate that wind velocities were greater from the northeast than from the southeast, but that the duration and wind movement were greater from the southeast sector.

SWELIS

The height and direction of movement of swells were observed at $\mathrm{Palm}$ Beach during the 10-year period 1932-42. A total of 40,601 observations was made. Those observations were about equally distributed over the months of the year. The results of an analysis of the observations are given in table 4.

\section{WIND DIAGRAMS}

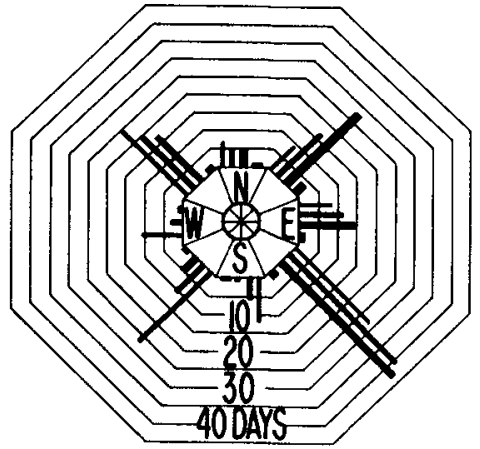

AVERAGE DIRECTION,DURATION AND VELOCITY OF WINOS FOR ONE YEAR AT WEST PALM BEACH,FLORIDA VELOCITIES MPH

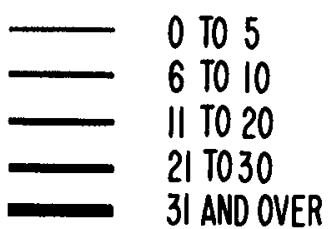

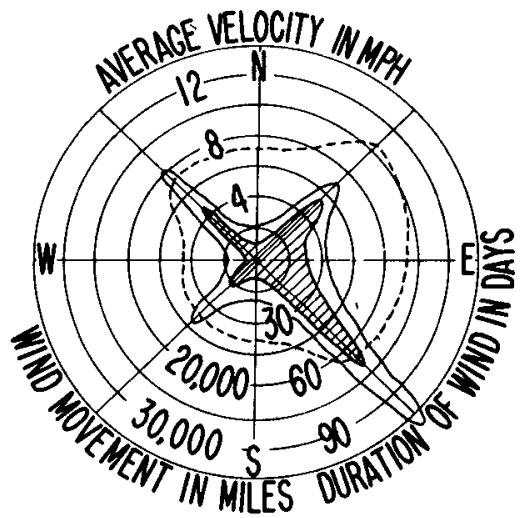

AVERAGE VELOCITY.DURATION AND MOVEMENT OF WINDS FOR ONE YEAR AT WEST PALM BEACH,FLORIDA AVERAGE VELOCITY IN MPH DURATION OF WIND IN DAYS WIND MOVEMENT IN MILES

Fig. 3 
COASTAL ENGINEERING

TABLE 4

Swell duration and direction

\begin{tabular}{|c|c|c|}
\hline & Duration (pet. of & time \\
\hline Dir & $\begin{array}{l}\text { Low swells Medium swells } \\
\begin{array}{ll}(1-6 \mathrm{ft} .) & (6-12 \mathrm{ft} .)\end{array}\end{array}$ & $\begin{array}{l}\text { High swells } \\
\text { (over } 12 \mathrm{ft} . \text { ) }\end{array}$ \\
\hline
\end{tabular}

\begin{tabular}{|c|c|c|c|}
\hline $\begin{array}{l}\text { North-. } \\
\text { Northeast-- } \\
\text { Bast- } \\
\text { Southeast-- }\end{array}$ & $\begin{array}{r}5.0 \\
10.2 \\
11.8 \\
9.8\end{array}$ & $\begin{array}{l}1.6 \\
6.3 \\
4.4 \\
1.2\end{array}$ & $\begin{array}{l}- \\
3.8 \\
1.8 \\
0.5\end{array}$ \\
\hline $\begin{array}{l}\text { South--.-- } \\
\text { Southwest-- } \\
\text { West- } \\
\text { Northwest-- }\end{array}$ & $\begin{array}{l}3.7 \\
7.6 \\
2.2 \\
2.2\end{array}$ & $\begin{array}{l}- \\
1.8 \\
2.2 \\
4.0\end{array}$ & $\begin{array}{l}0.4 \\
- \\
-\end{array}$ \\
\hline
\end{tabular}

The records indicate that the greatest exposure is from the northeast an east. That pattern is greatly influenced by the shelter afforded this portion of the coast by the islands of the Bahama group.

\section{WAVES}

Wave observations were made at Rainbow Pler, Palm Beach, during the period April-October 1939. A record of the height and period of waves also obtained there between March and June 1952 and since February 1954. The water depth at the observation point ranged from 12 to 15 feet. The maximum monthly waves during the period of observation varied from $7.0 \mathrm{t}$ 9.5 feet in height with periods of from 4 to 13 seconds. In the period between March and June 1952, the maximum wave height was 3.0 feet and three-fourths of all waves were between 0.6 and 1.0 foot. The wave peri ods ranged up to 18.9 seconds, with 29 percent of all periods between 4 . and 5.9 seconds. Observations of the direction of wave travel during th same period indicated that about 65 percent of all waves measured approsched from a 40-degree sector between azimuths (true) $80^{\circ}$ and $120^{\circ}$. has been reported that waves of sufficient height and force to carry san over the top of the seawalls (top elevation $16.0 \mathrm{ft}$.) were experienced 1 the vicinity of Rainbow Pier during the storm of September 1928.

\section{TIDES}

The mean range of tide in the Atlantic Ocean at Palm Beach is 2.8 feet; the spring range is 3.3 feet. The estimated lowest tide is $2.0 \mathrm{fe}$ below mean low water. Water-level variations of as much as 7.0 feet hav occurred during hurricanes. The maximum high water of record observed a Palm Beach was 11.2 feet above mean low water during the hurricane of Se tember 1928, including the effect of waves and runup. The second highes water elevation observed was 8.7 feet during the hurricane of July 1936 . 


\title{
EFFECT OF LAKE WORTH AND SOUTH LAKE WORTH INLETS ON THE MOVEMENT OF LITTORAL MATERIAL
}

\author{
CURRENTS--IAKE WORTH AND SOUTH LAKE WORTH INLETS
}

\section{OBSERVATIONS}

Current observations were made in the jettied channel at Lake Worth Inlet from June to September 1939, which was in the season of northward littoral drift. The observations indicated that tidal currents in Iake Worth Inlet were high. A tidal current velocity of 3 miles or less an hour is usually found, with an occasional maximum velocity of about twice that rate. No quantitative data are available for tidal velocities at South Iake Worth.

\section{LITIORAL CURRENTS}

Iittoral currents along the beach are clused by the action of swells and waves to which the beach is exposed. Because of the configuration and bearing of the shoreline under consideration--in a practically north-south alinement--swells and waves approaching from the north and northeast cause a southerly littoral current; swells from the south and southeast cause a northerly littoral current. Swells and waves from the east approach normal to the shoreline and create very little current in either direction. The wind data previously presented indicate that the area is exposed to winds producing a northerly littoral current for a greater percentage of time than winds producing a southerly littoral current. However, the winds from the north and northeast are stronger and more effective since the coast is not shielded from waves approaching from those directions by the islands of the Bahama group. Hence, it is found that the southerly littoral current predominates. Detailed examination of the records indicates that during the months of September through February the prevailing and predominant swells and waves approach from the north and northeast and set up a southerly littoral current; during March, April, and May the winds tend to be variable and low in strength, with no predominant trend discernible; and from June through August the winds and resultant predominant waves and swells approach from the south and southeast and set up a northerly littoral current. The Gulf stream is approximately parallel and from 3 to 5 miles offshore at this point. It is possible that a secondary current flowing southerly is generated in the area by the Gulf Stream. Such a current would tend to augment the southerly littoral currents and retard northerly littoral currents. However, there are not sufficient data to determine the magnitude of the influence from that source, since it is of considerably smaller magnitude than the currents generated by swells and waves.

There have been several efforts to determine the magnitude of the littoral currents. The first, during the period June to September 1939, indicated a predominantly northward current approximately parallel to the shore. In the angles formed by the beaches and jetties, reversals in the current were noted. Current velocities observed close to shore were too low to erode material from the beach but were capable of moving beach material placed in suspension by wave action. Higher velocities were found in the deeper water offshore where the currents were capable of eroding and transporting beach material. 


\section{COASTAL ENGINEERING}

During the period March 6 to June 10, 1952, a series of observations were made in the reach directly north of South Lake Worth Inlet. In thos observations, fluorescein dye was used to measure currents within the breaker zone. A small paper bag containing gravel and the dye was thrown into the surf zone, and the velocity of the current was determined by tim ing the travel of the stain. The observed data are summarized in table 5

\section{TABLE 5}

\section{Littoral current data}

\begin{tabular}{|c|c|c|}
\hline \multirow{2}{*}{$\begin{array}{l}\text { Iocation } \\
\text { (miles north of } \\
\text { South Lake Worth } \\
\text { Inlet) }\end{array}$} & $\begin{array}{l}\text { Accumulated duration } \\
\text { (pct. of time) } \\
\text { Velocity (ft./min.) }\end{array}$ & \multirow{2}{*}{$\begin{array}{l}\text { Estimated } \\
\text { maximum } \\
\text { (ft./min.) }\end{array}$} \\
\hline & 0 to $9 \quad 10$ to $49 \quad 50$ to 89 & \\
\hline
\end{tabular}

PERIODS OF NORTHERLY DRIFT

$\begin{array}{rrrrr}0.5 & 8.1 & 63.7 & 92.0 & 130 \text { to } 139 \\ 2.0 & 6.1 & 63.2 & 91.7 & 130 \text { to } 139 \\ 5.0 & 9.4 & 62.2 & 92.5 & 160 \text { to } 169 \\ 7.0 & 14.4 & 86.6 & 99.0 & 90 \text { to } 99\end{array}$

\section{PERIODS OF SOUTHERLY DRIFT}

$\begin{array}{lllll}0.5 & 15.2 & 59.3 & 88.2 & 120 \text { to } 129 \\ 2.0 & 17.7 & 72.5 & 85.3 & 140 \text { to } 149 \\ 5.0 & 14.3 & 60.7 & 87.3 & 130 \text { to } 139 \\ 7.0 & 13.8 & 62.2 & 93.2 & 110 \text { to } 119\end{array}$

Examination of the data indicates that during this period (March-June) $t$ velocity was under 89 feet per minute about 90 percent of the time and under 50 feet per minute about two-thirds of the time. The observations found no predominant current during this period and a current from eithe a northerly or southerly direction of about the same intensity could be expected, depending largely on wind conditions.

\section{LITTORAL MATERIALS}

The beach material is a mixture of silica sand and fragments of cor and shell. The silica sand is generally agreed to have been carried to the sea by the Savannah, Altamaha, and other rivers of Georgia and the Carolinas, and gradually shifted to the southward by shore currents and wave action. The underlying material is shell and coral sand which has been laid down during past periods of emergence. It varies in composit: and texture from coarse sandstone formed of consolidated coral sand (mar erated shells) to a compact mass of only slightly worn shells. In sevej places along the beach, the coquina rock appears as a submerged reef thi generally parallels the shoreline. The rock reef appears at various di: tances offshore from the low-water line to 1,000 feet offshore. Sample: indicate that the composition of the beach material on the surface of $t$ ] 


\section{EFFECT OF LAKE WORTH AND SOUTH LAKE WORTH INLETS ON THE MOVEMENT OF LITTORAL MATERIAL}

foreshore is about 40 percent fine siliceous sand and 60 percent shell and coral fragments. The median diameter of beach material at mean sea level and at 6-, 12-, 18-, 24-, and 30-foot depths ranges from 0.15 to 1.13 millimeters, with average median diameters of about 0.64 millimeter at sea level and 0.19 millimeter at 30 -foot depth. Detailed summary of the composition of the littoral material from samples obtained in 1956 is given in tables 6 and 7 .

\section{TABLE 6}

Composition of littoral material along beach

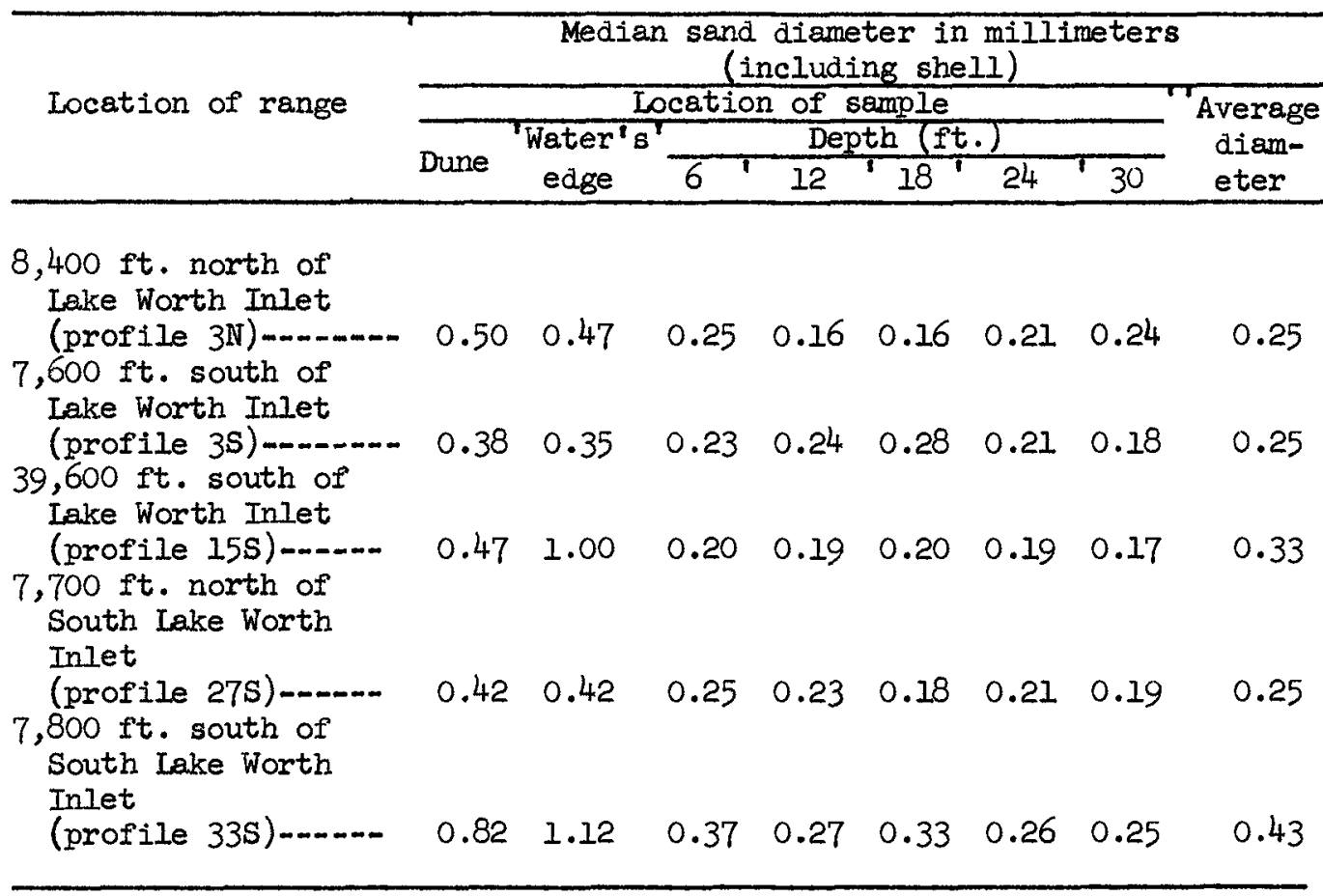


COASTAL ENGINEERING

\section{TABLE 7}

Composition of littoral material along alinements of Lake Worth and South Lake Worth Inlets

\begin{tabular}{llccc}
\hline \multirow{3}{*}{ Location } & Location of sample (depth in feet) \\
\cline { 2 - 5 } & 20 & 27 & 50 & 75 \\
\hline
\end{tabular}

ALONG ALINEMENT OF IAKE WORTH INLET

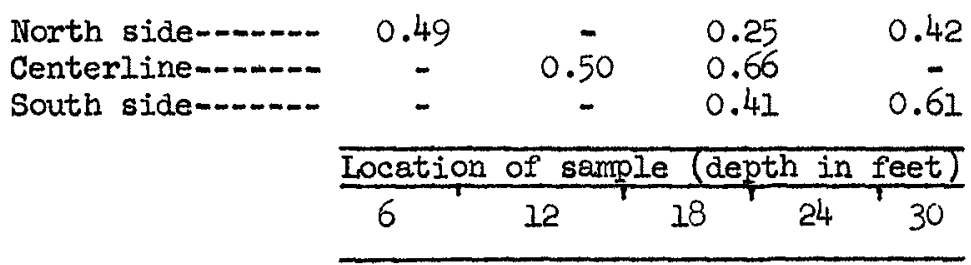

ALONG ALINEMENT OF SOUTH IAKE WORTH INLET

$\begin{array}{llllll}\text { North side-.... } & 0.46 \quad- & 0.26 & 0.24 & 0.24\end{array}$

South side-....- $0.70 \quad 0.24 \quad 0.25 \quad 0.25 \quad 0.25$

It can be readily seen that the tidal currents within the zone affected Lake Worth Inlet must be of considerably greater magnitude than the nom offshore littoral current. Wave action re-sorts the littoral material moving alongshore and the stronger tidal currents remove a large portio of the finer components offshore into deeper water. At South lake Wort Inlet, the tidal currents also remove the littoral material. However, cept at very shallow depths, a smaller percentage of the finer componen is removed.

\section{SHORELINE AND OFFSHORE DEPTH CHANGES}

GENERAL

Surveys made by the United States Coast and Geodetic Survey in $18 \varepsilon$ and 1928 and by the Corps of Engineers in 1946 and 1955 form the basis determining shoreline and offshore depth changes since the dredging of Iake Worth and South Lake Worth Inlets. There is also available a sur made by the Lake Worth Inlet District in the vicinity of the inlet in 1918, immediately before the inlet was constructed. Changes in the ger eral vicinity of Lake Worth Inlet are shown on figures 4 and 5; those the vicinity of South Lake Worth Inlet are shown on figure 11. Typica: bottom profiles are shown on figures $6,7,8,9,12$, and 13 .

FROM 1883 TO 1929

Comparison of the surveys indicates that in the period 1883 to $19 \%$ there was a general recession of from 125 to 165 feet in the shoreline 
EFFECT OF LAKE WORTH AND SOUTH LAKE WORTH INLETS ON THE MOVEMENT OF LITTORAL MATERIAL

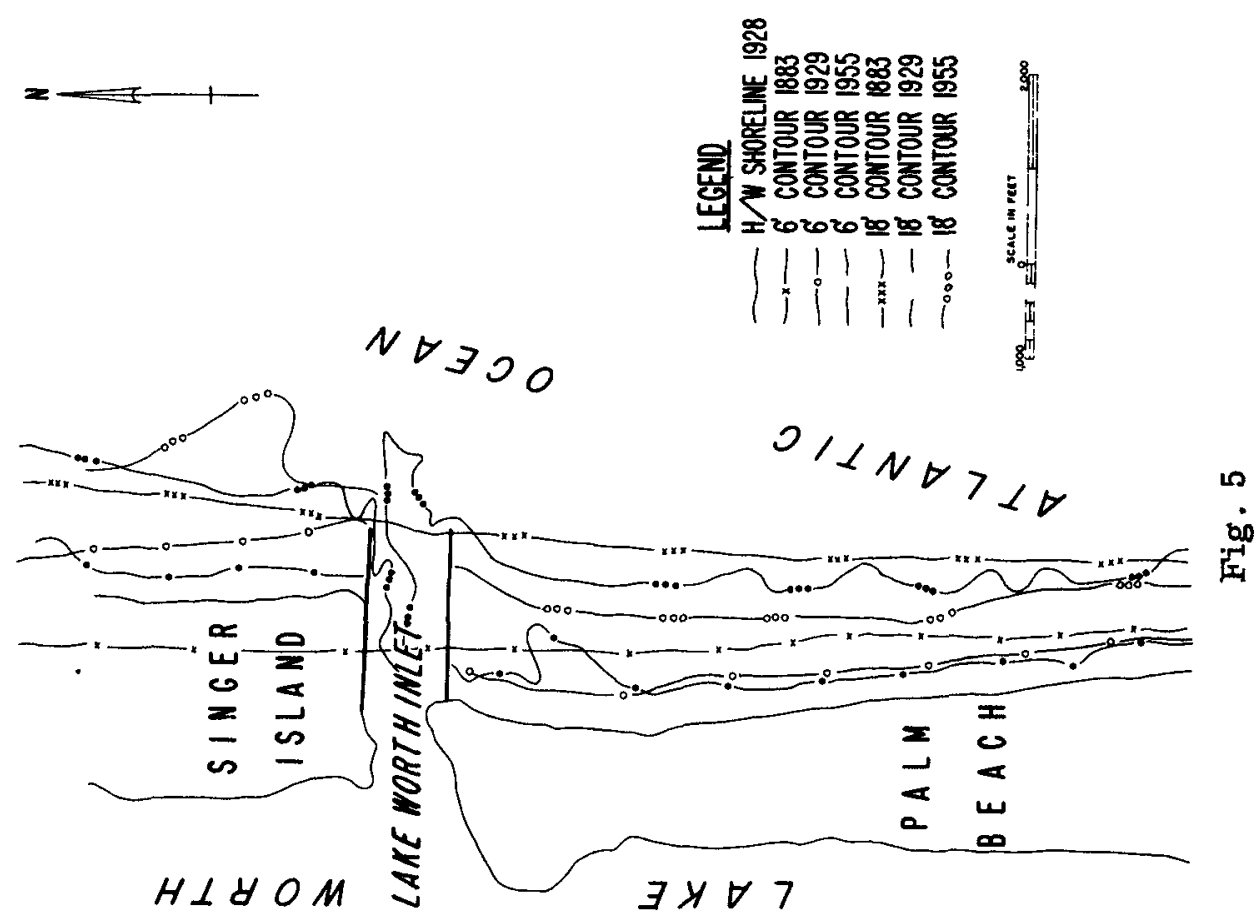
sio 


\section{COASTAL ENGINEERING}

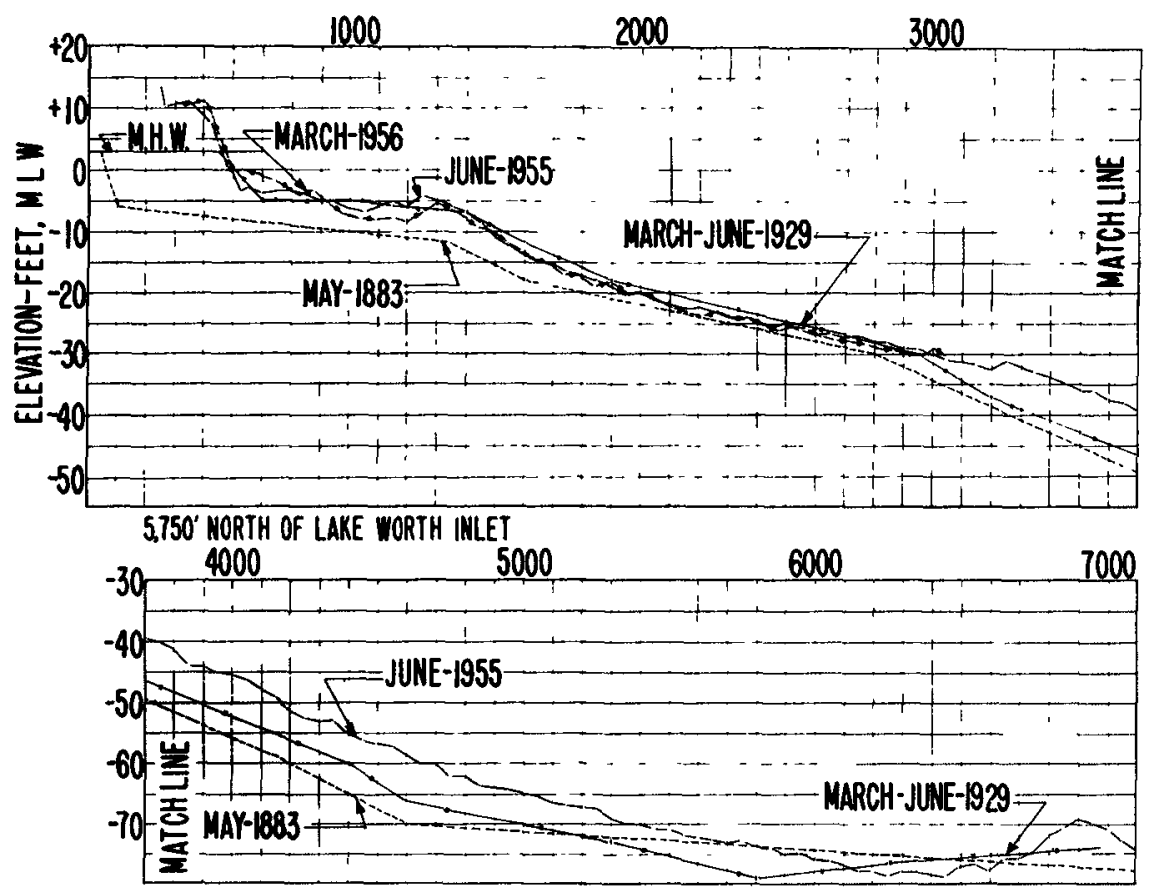

Fig. 6. Profile 2-N.

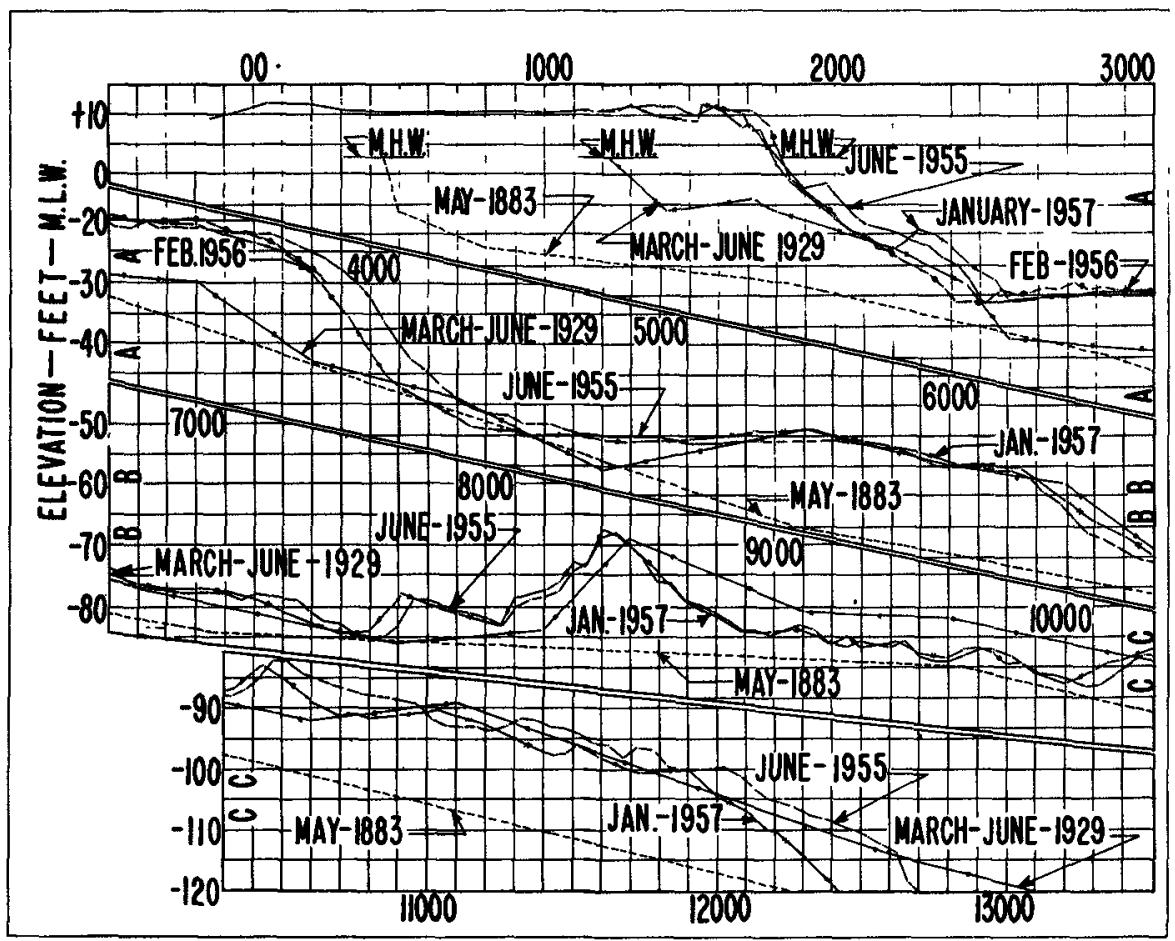

Fig. 7. Profile range 590-N (590 ft. N. of Lake Worth Inlet ). 
EFFECT OF LAKE WORTH AND SOUTH LAKE WORTH INLETS ON THE MOVEMENT OF LITTORAL MATERIAL
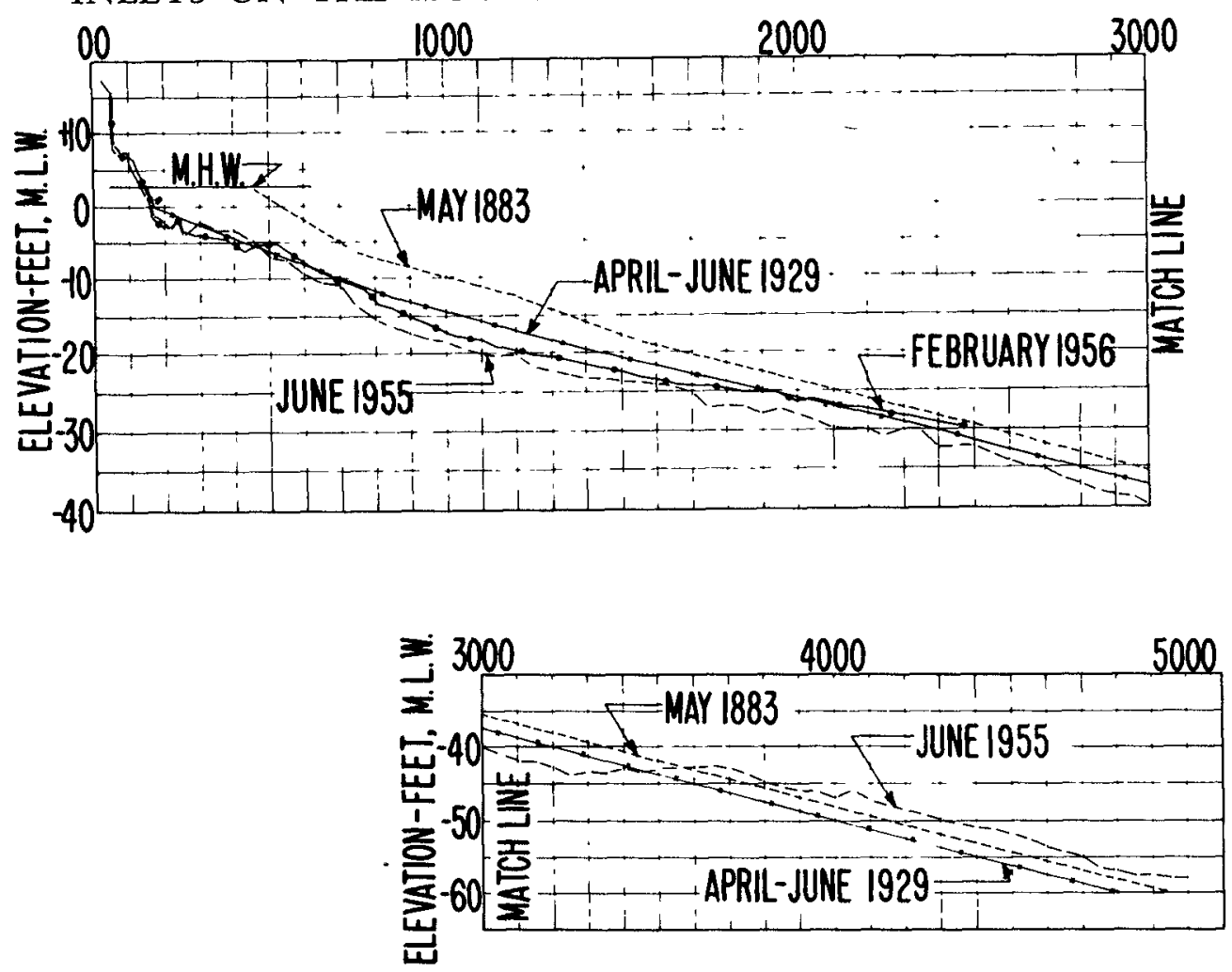

Fig. 8. Profile 2-S $(5,720 \mathrm{ft}$. S. of Lake Worth Inlet ).

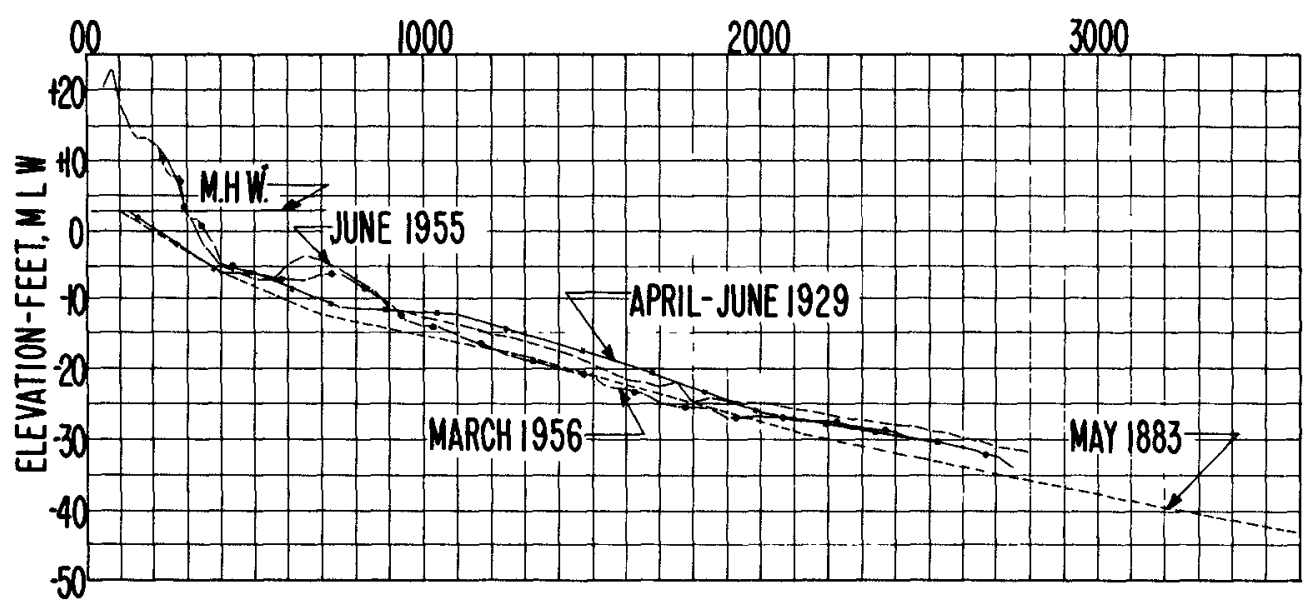

Fig. 9. Profile 14-S $(36,750 \mathrm{ft}$. S. of Lake Worth Inlet ). 
COASTAL ENGINEERING
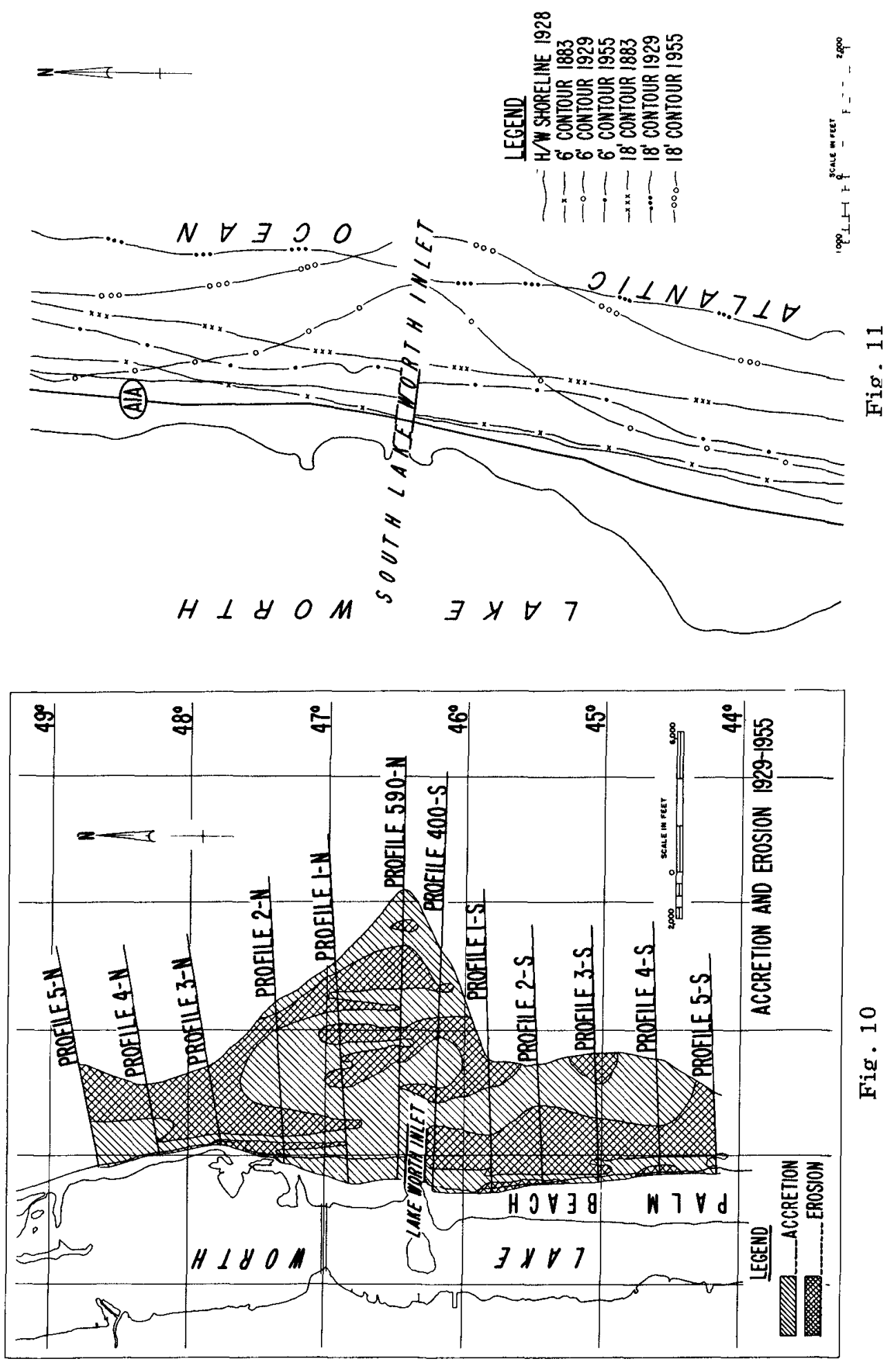
EFFECT OF LAKE WORTH AND SOUTH LAKE WORTH INLETS ON THE MOVEMENT OF LITTORAL MATERIAL

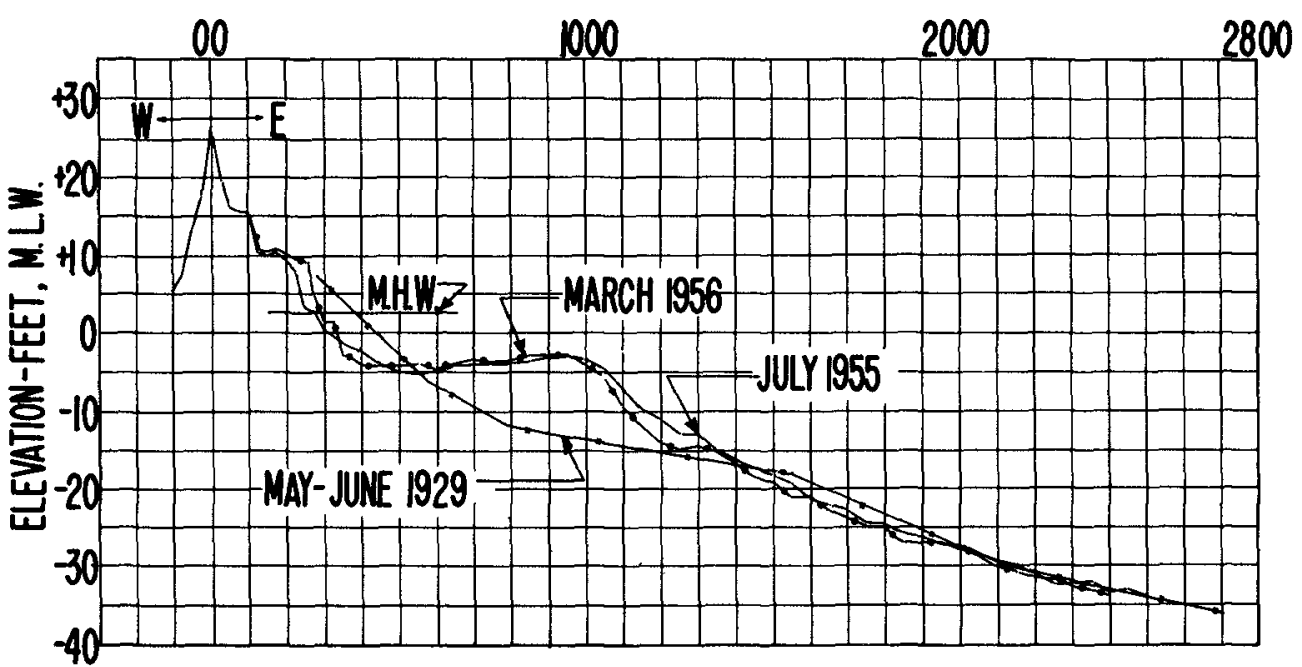

Fig. 12. Profile SLWI-1+00 (300 ft. N. of South Lake Worth Inlet).

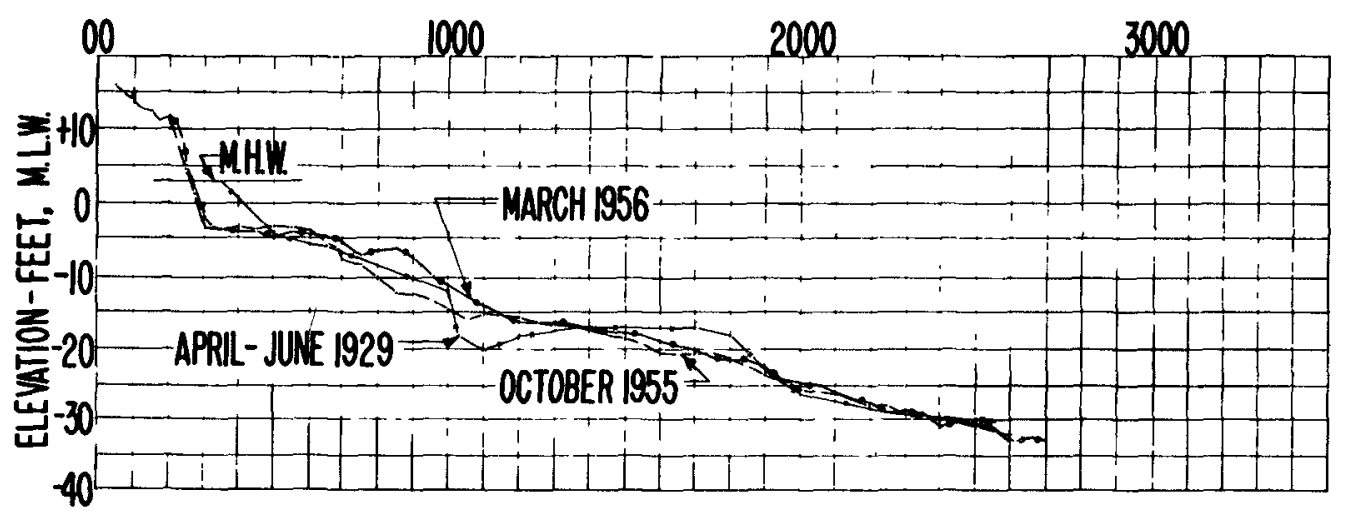

Fig. 13. Profile 31-S (2650 ft. S. of South Lake Worth Inlet). 


\section{COASTAL ENGINEERING}

except in the 1-1/2 miles Immediately north of Lake Worth Inlet. Generally, with the exception of a 3-mile reach south of the inlet, the surveys indicate advance during that period of from 150 to 380 feet in 6foot, 12-foot, 18-foot, and 30-foot offshore depths. It is probable that the effects noted were a result of the 1926 and 1928 hurricanes. Those hurricanes caused widespread damage to beach protective works and exposer buildings. It was reported that a lowering of the beach from 2 to 3 feet occurred in the 1928 hurricane.

The advance of the shoreline in the reach immediately north of the inlet probably is a result of the littoral barrier created by excavation of the inlet and construction of the protective jetties between 1918 and 1925. The maximum accretion occurred in depths of from 6 to 12 feet where those contours moved oceanward a maximum of 950 and 1,125 feet, respectively, with average movements of 630 and 290 feet respectively. The accretion extended to the maximum 30-foot depth covered by the surve: with slightly less accretion in the greater depths.

\section{FROM 1928 TO 1955}

In the period between the 1928 and 1955 surveys, there was a genera recession of the beach except where the natural beach was affected by construction of coastal works. The 6-foot depth contour advanced in som reaches and receded in others, with a general recession south of a point about 8 miles south or downdrift of Lake Worth Inlet. At depths of 12 , 18 , and 30 feet, an average recession of from 130 to 200 feet was experi enced along the entire reach of coast under consideration except in the general vicinity of Lake Worth Inlet. It appears that the relatively stable beach through the surf zone for the 8-mile reach imediately sout of Lake Worth Inlet was the result of the rather extensive groin system and the artificial nourishment of the beach. In August 1944, about 280,000 cubic yards of material from lake Worth was placed on the beach about 1,500 feet south of Lake Worth Inlet. Between May and November 1948, four stockpiles of sand with an aggregate volume of about $2,400,00$ cubic yards were pumped on the beach.

The accretion of the beach north of Lake Worth Inlet continued unde the influence of the jetties constructed to protect the inlet. However, analysis of the surveys indicates that the rate of accretion had been somewhat slower. The maximum advance of the beach was limited to a I/2mile reach immediately north of the inlet. The overall advance of the shoreline in the 27-year period (1928-55) was about 600 feet, while an advance of about 500 feet was experienced in the period of about 10 year immediately after completion of the north jetty. The 1955 survey also i dicated erosion of a portion of the material deposited immediately after the construction of the jetty in depths of about 18 feet of water. That erosion was probably caused by the tidal flow through the inlet where a 27-foot channel has been maintained. Accretion during that period continued at 30-foot depth, indicating that hydraulic forces continue to $r e$ sort and re-arrange the deposited material until it approaches the most stable position. There is a distinct tendency for the tidal currents tc 


\section{EFFECT OF LAKE WORTH AND SOUTH LAKE WORTH}

INLETS ON THE MOVEMENT OF LITTTORAL MATERIAL

erode and transport the littoral materials, redepositing them in a typical fan with a maximum elevation of about that of the maintained channel.

At South Lake Worth Inlet, there was a small accretion of material which reached a maximum at the inlet and extended from 2,000 to 3,000 feet on either side of the inlet (see figure 11). The 6- and 12-foot contours advanced a maximum of about 800 feet, while somewhat less advance was experienced at greater depths. The 30-foot contour advanced about 300 feet at the inlet. Operation of the sand-transfer plant from the time the inlet was constructed--with the exception of several years during World War II--maintained the normal flow of littoral material and tended to limit the erosion downdrift of the inlet.

Tidal currents have also conveyed a considerable volume of littoral material into Lake Worth and South Lake Worth Inlets. Examination of the dredging records indicates that about 1,450,000 cubic yards were removed from the Iake Worth Inlet channel during the period 1929-55. A middleground shoal known as Peanut Island was formed at the inlet. Records of maintenance dredging at South Iake Worth Inlet are not available, but periodic maintenance has been required to keep the inlet open.

\section{VOLUME OF IITIORAL DRIFT}

The continued erosion of the $\mathrm{Palm}$ Beach shore is an indication that the flow of littoral material is less than the ability of the littoral currents to transport material. The excess capacity has been used to erode and transport sedimentary material deposited during some earlier period when an excess of material was transported to the area. It appears from the scanty survey data available that there was a deficiency of supply with consequent erosion of the beach prior to construction of the inlet protective works. Since their construction, the inlet jetties at Lake Worth have augmented the deficiency in two ways: First, by creating conditions favorable for deposition in the reach updrift of the works, and, second, by increasing tidal currents, thus tending to move material either into the inlet channel or oceanward. From 1929 to 1955, surveys of the area to 100-foot depth showed an accretion of 3,768,000 cubic yards in the fillet immediately updrift from the north jetty. As previously stated, about 1,450,000 cubic yards were removed from the channel during that same period, including the inner bar and the outer portion of the channel between the jetties. In addition, there was an accretion of 676,000 cubic yards in the area seaward of the jetties and channels, as shown on figure 10. Assuming that the jetties were a practically complete barrier, the total volume of littoral material thus placed into a more or less permanent deposit amounted to about $6,000,000$ cubic yards, an annual rate of about 230,000 cubic yards.

It is also possible to estimate the capacity of the littoral currents by analysis of the erosion which has occurred in the reach between Lake Worth and South Lake Worth Inlets. Surveys indicate that about $8,800,000$ cubic yards of beach material were lost in that reach between the 1929 and 1955 surveys. Of that volume, 6,500,000 cubic yards were 


\section{COASTAL ENGINEERING}

lost from depths of 18 feet or more and 2,300,000 cubic yards in depths of less than 18 feet. In addition, about $3,000,000$ cubic yards of material placed on the beach between 1944 and 1953 were lost. The total los: was thus $11,800,000$ cubic yards or an annual rate of loss or deficiency in supply of about 450,000 cubic yards.

At South Lake Worth Inlet, the sand-pumping plant has maintained a portion of the littoral drift. Since the channel depth is about 6 feet, there has also been a considerable flow of littoral material around the inlet; therefore, it is impossible to make an analysis similar to that made above for Iake Worth Inlet.

\section{CONCLUSIONS}

Lake Worth and South Lake Worth Inlets have materially affected the flow of littoral material along the reach of coastline under consideration. The initial effect at Iake Worth Inlet was primarily due to the works provided to protect the channel. In recent years, the effects of tidal circulation in the inlet have become more important as the accretion in the fillet north of the inlet has approached stability. At Soutr Lake Worth Inlet, the effect has been much less significant because of the limited deepening of the maintained channel and operation of the sand-transfer plant since the inlet was constructed.

It is the conclusion of the writer that the deficiency in the supply of Ilttoral material to the beach south of Lake Worth Inlet is due tc a reduction in the volume of littoral material moving along that portion of the coast which has been aggravated by the circulation system established by the inlet. Analysis of the rate of accretion in the vicinity of Iake Worth Inlet indicates that the reduction of supply in recent years may have amounted to as much as 50 percent.

Tidal currents in the inlet interfere with the normal littoral currents and transfer the material to deep water where it becomes more or less permanently deposited. The lake Worth Inlet material has been deposited in depths up to 120 feet.

Finally, the survey indicates that there is a substantial movement of the littoral materials at depths of 30 feet or more. Additional investigations should be made to determine the importance of those movements in beach stability.

\section{ACKNOWIEDGMENIS}

The data presented and the analyses thereof were accomplished in the Jacksonville District Office, Corps of Engineers, under the general supervision of Colonel Paul D. Troxler, District Engineer, and Mr. Joe J. Koperski, Chief, Ingineering Division. Appreciation of the Corps of Engineers' permission to use this material is acknowledged. Personnel assisting in the study included Bryan Cornwell, Thomas E. Brannen, and William J. Bryant. 